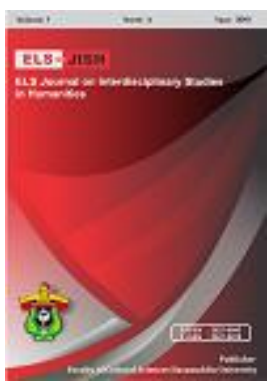

ELS-JISH

ELS Journal on Interdisciplinary Studies on Humanities

Volume 1 Issue 3, 2018

ISSN (print) : 2621-0843

ISSN (online) : 2621-0835

Homepage : http://journal.unhas.ac.id/index.php/jish

\title{
Bilingualism: Diglossia and Code-Switching of Indonesian Scholars
}

\begin{abstract}
Arjulayana $^{1}$
Abstract

arjulayana@umt.ac.id

Code switching and Diglossia's population can be found in variety places, both formal and informal places. This paper is aimed to report the data analysis relate with diglossia and code switching which is happen to Indonesian Scholar. For many reasons diglossia and code switching are parts of language varieties, and as the unique Indonesian characteristics, because not all countries are getting diglossia phenomenon. It happened only for country that has high and low languages use in their daily interaction. This belief assumes that diglossia and code switching as the varieties of language can be adapted to foster learner's ability, creativity, and awareness in practicing their language. The study is uses qualitative approach, with descriptive analysis. The purposive sampling is used to gain the data, with 5 questions in short answer form, and 5 questions with close ended question-answer to 16 higher students of 2nd semester from University of Muhammadiyah Jakarta majoring of religious education department. This research uses triangulation to know the validity of the data. The result of this research shows; firstly, bilingualism is a language varieties and happened in Indonesia with highest code-switching population can advocate Indonesia scholar to conserve one of local wisdom, and language varieties. Secondly, bilingual is familiar to Indonesian Scholar, because most of Indonesian scholars have their own local language. This also shown from their status in some social medias, way of interact; daily language uses, and etc. Thirdly, practicing bilingual is fun, and it could be good habit for them, because in special condition, sometimes their own language helps them to melt the situation in conversation context.
\end{abstract}

Keywords: Bilingual model, Diglossia, Code-switching, National-local language, Indonesian scholars

How to cite: Arjulayana. (2018). Bilingualism: Diglossia and Code-Switching of Indonesian Scholars. ELS Journal on Interdisciplinary Studies in Humanities, 1(3), 288-296.

\section{Introduction}

Indonesia as a big country, with consisting of many local languages, beside of the national language as a legal and formal language, it is Bahasa Indonesia. With multi-local languages make Indonesian scholars use bilingual in their daily life. Language as nation identity may not be separated from sociocultural studies. There are many societies and languages in line with country's development. Without any language people may not interact and send the message to anybody. This belief assumes that language in Indonesia has very urgent and potential function.

Indonesian scholars as the future generation may not allergic to their local language; in this phase they should use both languages in their daily life to interact in formal and informal condition. The population of using local language and national language among Indonesian scholars are very wide, because most of them have their own language to communicate among their families, rather than bahasa

\footnotetext{
${ }^{1}$ English Education Department, Muhammadiyah University of Tangerang
} 
Arjulayana. 1(3): 288 - 296

Indonesia as the national language. For more than many years Indonesian scholars are practicing bilingual or $\mathrm{s}$ multilingual for some people among their societies.

Moreover, discussing about language in context, means learning about sociolinguistics, because in socio linguistics studies will integrate about language uses; where the language is used, who are being use the language, why that language is used, what language is being popular and dominate, and many others, Tagliamonte (2006).

Code-Switching happens among language users with many reasons, for solidarity, group identity, more expression, show off and others, Turjoman (2016). For solidarity and expressing the message commonly code switching is occurring among Indonesian scholars. It is not taboo or breaks the culture when scholars communicated with code-switching, because Indonesia with multi-local languages adopted those. Due to that phenomenon, between family, and campus environments Indonesian scholars should communicate in different language in a day. For the example when they are at home they use Sudanese language, no more than 3 hours, when they come to the campus they need to use Indonesian language as the united language/national language.

Diglossia marks with high and low language uses, and it happens in Indonesia, because Indonesia has local language as the local identity among others, and Indonesia language as the national language. According to McKay and Hornberger (2010) that diglossia refers to the situation with two genetically language varieties, which identified with high $(\mathrm{H})$ and low $(\mathrm{L})$, which have clears distinctive function in the community. Based on the phenomenon that diglossia is rarely occur in the small city or village in Indonesia, but for Indonesian scholars who live in Jakarta it is very intents and simultaneously happens in daily communication.

Coming from researcher experiences when taught to her classroom, she watched many scholars communicate each other's with different languages spontaneously, and switches it also at the same time, but the listener is understand it. Be based on those reasons, this paper proposes to be the research, focusing on the sociolinguistics study.

This paper represent to find and report the research question regarding to the research focus above; 1) what is diglossia and code-switching?, 2) how does the phenomenon of diglossia and code-switching among Indonesian scholars occur?, 3) what languages are Indonesian scholars prefer to use in their daily communication, either in formal or informal situation?.4) What languages are Indonesian scholars master to communicate well in their societies (both national and local language)?

\section{Literature Review}

\subsection{Indonesian Scholar Phenomenon in Bilingual or Multilingual Model}

Learning sociolinguistics relates with bilingual or multilingual studies and social aspect of human being, refers to the language varieties in the society. Language variety can be seen from some aspects, domain of the language itself, language user, the use of language context, and function language in the social aspect; bilingual and multilingual societies. In bilingual or multilingual condition many language users are doing some phenomenon related with diglossia and codeswitching, because both of them are include the bilingual and multilingual processing. 
Turning from one language to others language addresses the speaker as the bilingual or multilingual speaker. Bilingualism is worldwide phenomenon, the speaker speaks and understand in two languages under of their consideration, McKay and Hornberger ( 1996), also in multilingualism it may be more than just magnified version and may be identified a specific social phenomenon, McKay and Hornberger (1996).

Many scholars who live in Jakarta are come from a rural area/migration. This phenomena can occur the bilingual or multilingualism among others, because scholars who come from others province they have their local language. That is why in Indonesian scholar multilingualism or bilingual occurred immediately. As Wardaugh and Fuller (2015) state that variety of multilingualism as the result of special local community in responding the local aspect and this multilingualism associated as the migrant status. This belief supported with the real fact in Indonesian scholar, when they came from out of Jakarta automatically they have and know others language or local language, at least one language beside of national language they master it.

People may not argue when someone said Indonesian scholars are belong to bilingual or monolingual model in their daily communication, because absolutely almost of people in the world are bilingual, Traxler (2012). This fact can be recognized clearly when people come to the public are, such as market, school, campus, or sometimes also in the road. In this reality Indonesian scholars may be identified as the bilingual or multilingual speakers in their communication, because most of them know and use more than one language in their regular basis.

\subsection{What is Code-Switching?}

In linguistics study code-switching may be defined in numerous linguists. In the bilingual and multilingual country, code-switching is occur regularly, because between speakers and listeners have mutual indelibility each other's. Code-switching defined as the alternative language use, when someone to express the message in the same condition and discourse, Poplack (1980). Code switching occurs among scholars sometimes just because they want to exclude the conversation from someone who does not understand their conversation, or the speaker wants to escape the message from someone around them, McKay and Hornberger (2010).

However, code-switching is not new phenomenon for Indonesian scholars, this occurs since elementary school until campus. Code-switching occurs in various situations for Indonesian scholar, and it may be denied, because as bilingualism or multilingualism the scholars need to practice those languages as their solidarity, politeness, and identity.

In code-switching each language uses is still same position, there is no dominating language. Code-switching also known in two types; extern codeswitching, and intern code-switching. Extern code-switching refers to language switches between 2 or more languages from different country, such as foreign language and Indonesian language. Intern code-switching refers to language switches between regional language or regional and national language, such as Indonesia language between Lampung or Sudanese language. 


\subsection{Definition of Diglossia}

Language variety has a native speaker and nonnative speaker. In bilingual or multilingual community language shifts occur in common situation. The shift of language can be identified as diglossia, this belief refers to Ferguson (1959) in Fishman (1966), where the diglossia can be identified in $\mathrm{H}$ and Low level. Still proposed by the Fishman and Ferguson that diglossia may be divided in some taxonomy; $\mathrm{H}$ as a classical, and formal spoken, $\mathrm{L}$ refers to vernacular, languages are genetically related or not being related to each other.

A community or groups of societies may use some languages in their interaction, but among them will have a dominant language to be used by them in every communication. When they spoke in dominating and no dominating language, means the diglossia is occurred.

Diglossia also occurs in Indonesia, it can be seen between market and school. Diglossia in classroom may be defined as the language situation in which the scholars speak with the dominant variety of language in that community only, not with their home language Wardaugh and Fuller (2015).

Diglossia refers to the function and situation also happened in Indonesia. The scholars use their regional language at home, market, or among their close friends. And they will use national language (bahasa Indoneisa) in their formal situation, such as at seminar, school, university, political ceremony and others.

\section{Research Design}

\subsection{Research Method}

There are 2 approaches in research method commonly used by researcher; quantitative approach, and qualitative approach. In this research the researcher uses qualitative approach with qualitative descriptive method. Where the primary data is the researcher itself and the secondary data is research instruments. The research instruments in this research are interview with indirect method, and study documents. The process of getting the data, starts from classroom observation, interview, and study document, the last activity is data analysis. Classroom observation is done to identify the language used among scholars related to diglossia and code-switching. The interview divided into two form; the first is interview with close answer, only depend on yes or no choices with the total question is 5 numbers, and the second interview is short answer question, where in this question scholars require to free answer depend on their understanding and their experiences. Those interviews are done to clarify the observation identification in previous observation, and also clarifying the diglossia and CS among others.

The total subject of the research is 16 scholars from religious study department of Universitas Muhammadiyah Jakarta, located at Cirendeu-Ciputat South Tangerang area. Those scholars are to be chosen because in their class they are very active in communication among others.

\subsection{Data Analysis}

From the classroom observation, diglossia and code-switching are commonly occurring among scholars in their class room, especially in English class. This happened because some of them still difficult to practice their English. Nevertheless, they tried to use others language to express their message. 
Diglossia as the phenomenon in bilingual or in multilingual community, but when the researcher asked the scholars' understanding about diglossia, from all the participant $56.3 \%$ particippants are do not know, and $43.8 \%$ known what diglossia is. $87.5 \%$ scholars are bilingual and multilingual, while $12.5 \%$ is monolingual. Diglossia acored to $87.5 \%$ scholars and $12.5 \%$ never do the language shift. Most of scholars also switched the language while speaking among their societies. $81.3 \%$ Indonesian scholars are using 2 or more language to communicate with their lecturer, families, friend in a day, and $18.8 \%$ never do it. Scholars prefer to use and keep their regional and national language to be able to communicate among others, because they knew that with multilingualism or bilingualism can improve brain waves.

From the short answer question, most of scholars master the national language $100 \%$ as their formal language, and Javanese $19 \%$, followed by others language such as Lampung, Sundanese, Sumbawa, Bataknese, Palembang, Arabic and etc.

\section{Findings}

Research finding of this paper can answer the research question, and prove the problem of the research as the identification in the pre observation before.

\subsection{What is Diglossia and Code-switching?}

Almost of scholars are do not know the diglossia nd code-switching in language community. This paper give understanding about diglossia and code-switching related to language use in language community. Diglossias as the dichotomy of language use in formalize and in formalize, Schiffman (1999). Bahasa Indonesia as the formal language and regional language (local language) such as Javanese, Sudanese, Lampungnese, and Bataknese as the informal language. Diglossia occurs when the scholar speaks Sudanese as the informal language and speaks bahasa Indonesia in formal situation, such as in the university and classroom while teaching and learning process occur. the underline one in diglossia phenomena is speaker may not think about language discrimination among others, diglossia just focusing on the high and low level standard only, or we may defined as the formal and informal situation Martine,M.M \& Sulentic (1999).

These diagrams can show the diglossia and Code switching accour among scholars:

Have you ever communicated in more than one languages in one day?

16 responses

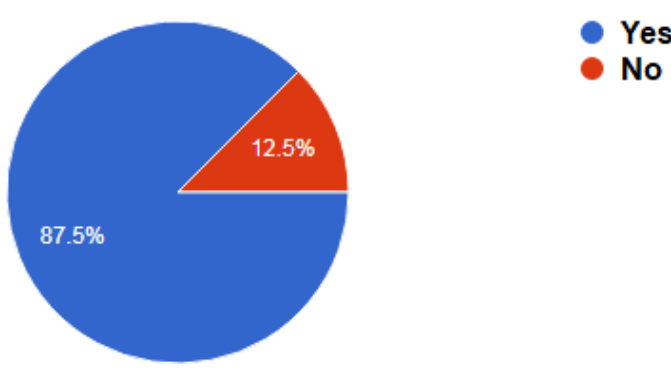

Figure 1. Diagram 4.1 


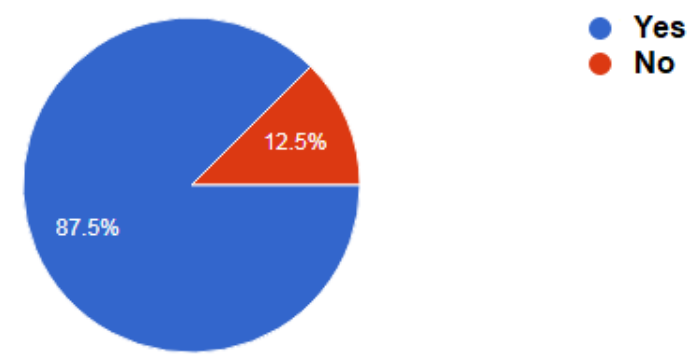

Figure 2. Diagram 4.2

Code-switching as shift codes from one language to another language intentionally or unintentionally, Eldin (2014). To show their solidarity, sometimes scholars switch the code in their language use. Also in hiding or avoiding the message to be understood by others listener, swift the code is commonly occur. In the other definition code switching also defined as the individual's speech with switch the code while using the language varieties, Woolard (2004).

\subsection{How does the phenomenon of diglossia and code-switching among Indonesian scholar occur?}

Regarding to the data analysis, diglossia occurs among Indonesian scholar intensively. Almost of them are migration, that is why they have and able to communicate in different language. In their home, relatives, friends, and market commonly they use their regional language, such as java, sundanese, and many others. $87.5 \%$ scholars are doing diglosia phenomena in their daily communication. It just depend on the situation, they will use bilingual in formal or informal language.

Diglossia occur in certain situation and they use taxonomy of ferguson and fishmann that their language community be based on high $(H)$ and low $(L)$.

In bilingual or multilingual scholars, code switching occurs as a common situation. No one can blame speaker when he/she occurred code switching. Almost of scholars did code switching in their communication, that's sometimes for their solidarity, community gap, avoiding some issues from public and others.

In this part diglossia may identify as the scholar ideology in using language varieties, because language use identically ideological and normative description, where it will be important to give the impact on the language meaning, Moestrup (2012). Therefore, both diglossia and code-switching can be stated as the indonesian scholars phenomenon in fostering language variety through communication.

\subsection{What languages are Indonesian scholars prefer to use in their daily communication, either in formal or informal situation?}

Language as a tool for communication, sometimes acquire the speaker to think hardly, what language they should use to interact, where they can use a formal and informal language. According to data analysis, Indonesian scholars prefer to use national language (bahasa Indonesia) in their formal situation, and use their 
regional/local language as their informal language, such as in the market, cheating with friends, siblings, parent, and others.

Indonesian as bilingualism or multilingualism scholar, able to use different language in the same time to communicate among people around them, if the people are come from different city and still strict to their local language. In the classroom Indonesian scholars use formal language, and they will interact with their lecturer or friends from different city with national language to show their politeness, and avoid from language gap.

Daily communication is not about their preference or not, but they will use those languages depend on the situation and the partners. If their partners are such a formal level, or they are in formal situation, using bahasa Indonesia should be practiced there.

\subsection{What languages are Indonesian scholars master to communicate well in their societies (both national and local language)?}

Most of Indonesian scholars master their national language and local language. For local language it will be depend on where they are come from. If they come from java, automatically they will master Javanese language, because java is not only their mother tongue, but also their first language.

In conclusion, Indonesian scholars are master national and their own regional language as their symbol of ethnicity. Bahasa Indonesia as the national language being learns and practice in all level school. Bahasa Indonesia will become one of the requirement also for Indonesian scholar when they have to finished from specific level of their study, such as when they will graduate from their high school they must follow the bahasa Indonesia test, that is why Indonesian scholar will master it as well as their mother tongue.

\section{Discussion}

This paper shows that diglossia and code-switching always happen together, especially to bilingualism and multilingualism situation. Diglossia as language variety refers to high and low user, or it may be defined as the formal and informal language. Local/regional language can show as the regional symbol, regional identity, as the integrated language among national and regional language, as the cultural support will always be improve and use simultaneously among scholars, Sitohang (2017).

Code-switching as the language shift also happen among Indonesian scholars. To express or showing their solidarity code-switching is very effective ways. Code switching become interest for scholars because it also can be implemented such a natural situation and to achieve particular interaction and conversation's goal, Shin (2010).

Based on the relevant studies also diglossia and code switching will occur together or intents among bilingualism and multilingualism scholar.

Beside of showing solidarity, expressing hide message to be understood by particular participant, code- switching also may occur because of forgetting or lacking the language target vocabulary but the speaker want to make the conversation is comprehensively by the listener, Tien and Liu (2006). According to the relevant study of Badrul (2009), with the title of his research teacher's code switching in classroom interaction for low English proficiency learning, stats that code switching as the 
Arjulayana. 1(3): $288-296$

language shift in communication and scholars interaction also can support them to be enjoy the learning and interaction among scholars or their environment. In this paper the writer stated that Code switching as students habit to gain their conversation and language learning able to comprehend easily.

\section{Conclusion}

Communication is the way to share some ideas and keep the relationship among people. In communication language as the primary tool, even though there many differences in the language use because of social background or mother tongue. Those reasons develop significantly among scholars, but to be able to avoid some misunderstanding, the use of national language is to be a requirement.

Indonesia with a multi local languages and national language adopt diglossia and code-switching among scholars and society in communication. Bahasa Indonesia as the national and formal language states as the high level language, and local language as the low level language.in formal situation bahasa Indonesia become the unifying language among diversities scholars.

Code-switching as the language shift can support solidarity among scholars, and to be used by the speaker to make the conversation easier in gaining the message and expressing the thought for the speaker.

In conclusion, diglossia and code-switching are the variety language among bilingualism and multilingualism, where this phenomenon is a common sense for Indonesian scholars.

\section{References}

Ahmad,B.H. (2009). Teachers' Code-Switching in Classroom Instructions for Low English Proficient Learners. Journal of English language Teaching. Vol.2.No. 2

Eldin Sharaf, A.A.T. (2014). Sociolinguisticsstudy Of Code Switching Of The Arabic Language Speakers On Social Media. International journal of English linguistics. Vol.4.No.6. Canadian center

Fishman,J.(1968). Originally Appeared in Language and Linguistic Monograph Series. Georgetown University No.12. : Linguistics department

Martine,M.M \& Sulentic. (1999). Inventing culturally relevant pedagogy in two fourth/fifth grade combinationclassroom; diversity and diglossia among blach English speakers. Doctoral dissertation. Graduate college of the university of Lowa.

McKay,L.S., Hornberger,N.H. (2010). Sociolinguistics and Language Education. New Perspective and Language Education .Techset Composition Ltd., Salisbury.UK and Short run press Ltd.

McKay,L.S.,Hornberger,N.H. (1996). Sociolinguistics and Language Teaching. Cambridge University press. NY.USA.

Poplack, S. (1980). Sometimes I'll start a sentence in Spanish y termino en espanol. Linguistics 26

Schiffman.F.H. (1999). Diglossia, Linguistic Culture and Language Policy in southeast Asia. Respiratory document. University of Washington. 
Shin, S. Y. (2010). The Functions Of Code-Switching In A Korean Sunday School. Heritage Language Journal. 7(1).

Sitohang,M.N.M. (2017). Penggunaan Bahasa Daerah Sebagai Bahasa Pengantar Dikelas Rendah Sekolah Dasar Dikota Palangkaraya. Jurnal suar bintang. Vol. 12. No. 2.

Tagliamonte.A,Sali. (2006). Analyzing sociolinguistic variation; key topic in sociolinguistic. Cambridge university Press. The Eidenburg Building. UK.

Tien, C and Liu, K. (2006). Code-switching in two EFL classes in Taiwan. In Azirah Hashim \& Norizah Hassan. (Eds). English in Southeast Asia: prospects, perspectives and possibilities. Kuala Lumpur: Universiti Malaya Press.

Traxler J.Mathew. (2012). Introduction to Psycholinguistics: Understanding Language Science. UK: Willey blackwel.

Turjoman,O,Mona. (2016). A New Phenomenon in Saudi Female's Code Switching: a Morphemic Analysis. Journal of Advances in language and literary studies.Vol.7.No.6

Wardhaugh,R \& Fuller,J.M. (2015). An Introduction to Sociolinguistics; Seventh Edition. Blackwell Publisher: UK.

Woolard, K. (2004). Codeswitching. In A. Duranti (Ed.), A Companion to Linguistic Anthropology (pp. 73-75). Oxford: Blackwell. 